Jurnal Pemberdayaan: Publikasi Hasil Pengabdian kepada Masyarakat

Vol. 3, No. 2, Agustus 2019, Hal. 211-224

ISSN: 2580-2569; e-ISSN: 2656-0542

DOI: https://doi.org/10.12928/jp.v3i2.449

\title{
Pemberdayaan masyarakat Tirtohargo dengan program eko-eduwisata Mangrove menuju konservasi taman pesisir di Bantul
}

\author{
Dedi Wijayanti, Suryani, Wahyu Budiman \\ Universitas Ahmad Dahlan Yogyakarta, Jl. Pramuka Sidikan Umbulharjo Yogyakarta \\ Email: dediwijayantiuad@gmail.com.
}

\begin{abstract}
ABSTRAK
Pantai Baros terletak di wilayah pesisir Kabupaten Bantul merupakan salah satu dari kabupaten di Propinsi DIY yang memiliki ekosistem mangrove. Tanaman mangrove diharapkan dapat mengurangi ancaman intrusi air laut, ancaman gelombang tsunami dan dampak gangguan angin laut yang mengancam pertanian masyarakat. Penanaman mangrove di Pantai Baros ini di masa yang akan datang prospeknya sangatlah besar bagi kemakmuran warga masyarakat sekitar asalkan mulai dari sekarang dimanfaatkan dengan benar. Terdapat peluang besar pengembangan kemakmuran masyarakat sekitar yaitu pengembangan wisata alam pantai yang sekaligus dapat berfungsi sebagai pusat pendidikan lingkungan pesisir di Yogyakarta. Metode yang digunakan dalam pelaksanaan KKN PPM ini partisipatif masyarakat dan pihak terkait. Dalam hal ini, secara teknis semua kebijakan dan kegiatan yang dilaksanakan selama KKN PPM ini selalu berkoordinasi dengan pemerintah daerah setempat, dalam hal ini Bappeda Bantul sampai dengan pemerintah desa dan melibatkan SKPD terkait. Hasil dari kegiatan KKN PPM ini adalah penyelenggaraan pelatihan SDM, pengadaan kolam terpal di 2 dusun dan keramba jaring apung di muara sungai, pengadaan bibit ikat dan pakan di 3 dusun, penanaman mangrove 1000 batang di kawasan konservasi, pengadaan solar panel atau pembangkit lisrik tenaga surya yang dipasang di pondok jaga di kawasan mangrove Pantai Baros, pembangunan green house di kawasan kandang terpadu kelompok ternak Andhini Lestari di Dusun Baros, pengadaan bibit tanaman buah dan toga di 3 dusun, pembangunan dermaga mini Pantai Baros dan jembatan bambu di kawasan konservasi, pendesainan data yang akan ditampilkan dalam website KP2B sebagai media promosi eko eduwisata mangrove, merancang dan membuat media promosi berupa brosur, pembersihan sampah di kawasan konservasi, dan pengadaan buku bacaan anak yang bertema lingkungan.
\end{abstract}

Kata kunci: pengembangan, mangrove, eko eduwisata

\begin{abstract}
Baros beach is located in coastal areas of Bantul Regency, one of the regencies in the Special Region of Yogyakarta that has mangroves ecosystem. Mangroves are expected to reduce sea intrusion, tsunami, and impact of sea breeze that endanger agricultural activities of the society. The cultivation of mangroves in Baros Beach is potentially great for the prosperity of the surrounding society, as long as it is managed properly. There is a big opportunity to increase the prosperity of the society by developing the beach as tourism attraction which also functions as the central of education in Yogyakarta coastal area. This Students Lecturers Community Service Program uses participatory method, involving the society and related stakeholders. In this context, technically, all policies and activities implemented during this program are always in line with the local government, particularly the Development Planning Board of Bantul, as well as the district government. Besides, it involves the relevant regional work unit such as Maritime and Fisheries Services of Bantul Regency, Tourism Services of Bantul Regency, and Environmental Agency of Bantul Regency. The Community Service Program of PPM has conducted programs as the following Human Resource Training, procurement of tarpaulin ponds in 2 hamlets and floating net cages at the mouth of the river, procurement of bundle seedlings and feed in 3 hamlets, mangrove planting of 1000 stems in the conservation area, the procurement of solar panels or solar power plants installed in the guard huts in the mangrove area of Baros Beach, construction of green house in integrated cage area of Andhini Lestari livestock group in Baros hamlet, provision of fruit and toga seedlings in 3 hamlets, construction of Baros Beach mini docks and bamboo bridges in conservation areas, designing the data to be displayed in the $K P 2 B$ website as a promotional media for eco mangrove edutourism, design and make promotional media in the form of brochures, waste cleaning in conservation areas, and the procurement of children reading books with environmental themes.
\end{abstract}

Keywords: developing, mangroves, eco edutourism 


\section{PENDAHULUAN}

Kegiatan Pengabdian kepada masyarakat yang dilakukan oleh Universitas Ahmad Dahlan (UAD) Yogyakarta dikoordinasi oleh Lembaga Penelitian dan Pengabdian kepada Masyarakat (LPPM) sebagai lembaga tingkat universitas yang bertugas melaksanakan kegiatan edukatif di bidang pengabdian kepada masyarakat. Sejak awal berdirinya LPPM UAD telah melaksanakan berbagai kegiatan pengabdian kepada masyarakat, baik yang dilakukan oleh dosen (disebut Program Pengabdian kepada Masyarakat/PPM) maupun oleh mahasiswa (disebut Kuliah Kerja Nyata/KKN).

Surat Keputusan Bupati Bantul Nomor 284 Tahun 2014 Tentang Pencadangan Kawasan Konservasi Taman Pesisir di Kabupaten Bantul telah menetapkan luas area untuk kawasan konservasi penyu sebesar 50 ha dan luas untuk kawasan konservasi mangrove sebesar 132 ha. Sedangkan berdasarkan Peraturan Daerah Kabupaten Bantul Nomor 04 Tahun 2011 Tentang Rencana Tata Ruang Wilayah Kabupaten Bantul Tahun 2010-2030 mengemukakan bahwa wilayah pesisir Desa Tirtohargo termasuk ke dalam kawasan perlindungan setempat berupa sempadan pantai dan sempadan sungai. Selain itu, peraturan tersebut juga menetapkan Desa Srigading dan Desa Tirtohargo termasuk ke dalam kawasan suaka alam, pelestarian alam, dan cagar budaya berupa kawasan pantai berhutan bakau. Hal inilah yang melatarbelakangi awal mula gagasan dari kegiatan KKN PPM (Kuliah Kerja Nyata Program Pengabdian kepada Masyarakat) yang mengusung tema Pengembangan Hutan Mangrove Menuju Kawasan Konservasi Taman Pesisir di Tirtohargo Kretek Bantul Yogyakarta yang pada akhirnya mendapat pendanaan dari Kemenristek Dikti di tahun 2017 ini.

Kawasan Tirtohargo yang memiliki ekosistem mangrove dan telah ditetapkan sebagai kawasan konservasi mangrove dalam pengelolaannya tidak boleh hanya dilakukan secara asalasalan. Pengelolaan sebuah kawasan sumber daya alam mensyaratkan komitmen dan kerjasama sinergis antar semua komponen yang terlibat. Perlu adanya kemitraan kerjasama antara pemerintah daerah, swasta, serta perguruan tinggi dalam rangka menunjang pembangunan daerah serta pengembangan kawasan tersebut. Tak terkecuali dalam mengembangkan kawasan ekosistem mangrove yang berada di Pantai Baros Tirtohargo Kretek Bantul ini. Terlebih konsep yang sudah dikembangkan selama ini oleh KP2B (Keluarga Pemuda Pemudi Baros) adalah konsep pengembangan kawasan edu-ekowisata mangrove Pantai Baros yang berbasis pada keilmuan, kemajuan iptek dan teknologi, tata kelola yang benar sesuai perundang-undangan. Tanpa itu, pengelolaan yang dilakukan tidak akan mampu mencapai hasil yang maksimal. Di samping itu, peraturan yang jelas dan tegas berkaitan dengan pengelolaan dan status kawasan juga menjadi aspek penting dalam menjaga keberlangsungan kawasan tertentu Penanaman mangrove di Pantai Baros ini di masa yang akan datang prospeknya sangatlah besar bagi kemakmuran warga masyarakat sekitar asalkan mulai dari sekarang dimanfaatkan dengan benar. Terdapat peluang besar pengembangan kemakmuran masyarakat sekitar yaitu pengembangan wisata alam pantai yang sekaligus dapat berfungsi sebagai pusat pendidikan lingkungan pesisir di Yogyakarta dan selain itu juga dapat dikembangkan perikanan payau dengan kolam jebak ataupun keramba jaring apung.

Saat ini pemanfaatan tumbuh-tumbuhan di ekosistem mangrove sebagai bahan pangan dan untuk pengobatan semakin meningkat. Buah dari tumbuhan mangrove dapat diolah menjadi bahan pangan pengganti makanan pokok yang mengandung karbohidrat. Dengan demikian, selain beras, ubi jalar, singkong/ubi kayu, talas, jagung, pisang, dan sagu, buah mangrove menjadi salah satu pilihan makanan pokok, khususnya karbohidrat. Sebuah penelitian membuktikan bahwa buah tumbuhan mangrove jenis tanjang (Bruguiera gymnorhiza) atau dikenal sebagai buah aibon mengandung karbohidrat yang tinggi yaitu 92,94\% hampir setara dengan singkong yang mengandung 92,5\% karbohidrat. Bahkan kandungan protein buah tanjang mencapai $4,06 \%$ lebih tinggi dari singkong yang hanya 3,19\% 
(Kordi, 2012). Selain itu, tumbuhan mangrove juga telah dikenal dalam pengobatan tradisional. Penggunaan kulit batang dan kulit akar, daun, dan buah mangrove untuk pengobatan sudah sejak lama di desa-desa pesisir dan pulau-pulau.

Ekosistem mangrove juga merupakan penyangga kehidupan di darat, karena berbagai hewan darat, termasuk burung hidup mencari makan di ekosistem ini. Bahkan menjadi tempat untuk mencari makan dan beristirahat bagi burung-burung migran antar benua. Selain itu, serasah daun dan ranting yang gugur merupakan sumber bahan organik penting dalam rantai makanan (food chain) di dalam lingkungan perairan. Daun dan ranting yang gugur ke dalam air akan segera menjadi bahan makanan bagi berbagai jenis hewan air atau dihancurkan lebih dahulu oleh kegiatan bakteri dan jamur. Hancuran bahan-bahan organik kemudian menjadi bahan makanan penting bagi cacing, krustase, dan hewan-hewan lain. Pada tingkat berikutnya, hewan-hewan ini pun menjadi makanan bagi hewan-hewan lainnya yang lebih besar dan seterusnya. Kesuburan perairan sekitar kawasan mangrove tergantung pada masukan bahan organik yang berasal dari guguran daun dan ranting tersebut.

Hal-hal itulah yang melatarbelakangi dilaksanakannya Program KKN PPM UAD tahun 2017 yang berlokasi di Desa Tirtohargo ini. UAD melalui KKN PPM-nya menerjunkan dosen dan mahasiswanya selama 35 hari untuk melaksanakan serangkaian program-program kegiatan tematik mangrove, keilmuan, keagamaan, olah raga dan seni budaya di 3 dusun yang ada di Desa Tirtohargo, yaitu Dusun Baros, Dusun Kalangan, dan Dusun Gegunung.

\section{METODE}

Dalam pelaksanaan kegiatan KKN PPM di tiga dusun di Desa Tirtohargo ini memuat metode dan tahapan sebagai berikut.

1. Persiapan dan Pembekalan yang meliputi:

a. Rekruitmen mahasiswa

b. Sosialisasi ke masyarakat pengguna program KKN

c. Persiapan mahasiswa dengan mengadakan pembekalan KKN yang terkait dengan tema keagamaan, keilmuan, olah raga dan budaya yang dilakukan di kampus.

d. Persiapan mahasiswa berikutnya adalah pembekalan kewilayahan yang dilakukan di aula Desa Tirtohargo yang dengan melibatkan pamong desa dan mitra sasaran program (KP2B).

e. Selain dua pembekalan di atas, mahasiswa juga diberikan pembekalan tematik (dalam hal ini tematik Pengembangan Pengelolaan Ekosistem Konservasi Mangrove) yang meliputi pembekalan pelatihan untuk sumber daya manusianya, pelatihan pengadaan pembuatan kolam terpal dan KJA (Keramba Jaring Apung), pelatihan penanaman mangrove, pelatihan pemasangan solar panel.

f. Penerjunan mahasiswa ke lokasi KKN

2. Pelaksanaan kegiatan meliputi sebagai berikut.

a. Penyusunan rencana dan mengadakan koordinasi dengan Bappeda Bantul serta dinas terkait, dan Kelompok Konsevasi Mangrove Baros yaitu KP2B sebagai mitra sasaran.

b. Pelatihan motivasi menuju desa wisata bagi tiga kalangan yaitu bapak-bapak, ibu-ibu, dan remaja; pelatihan service excelent (pelayanan prima); pelatihan pemanfaatan lahan kosong; pelatihan pembuatan kerajinan sampah laut yang berupa kayu dan juga sisa kayu meubel; pelatihan perakitan, pemasangan, serta perawatan pembangkit listrik tenaga surya; pelatihan pembuatan percontohan kolam, baik dengan media terpal KJA/Keramba Jaring Apung.

c. Pengadaan beberapa sarana dan prasarana pendukung di kawasan konservasi. 


\section{HASIL, PEMBAHASAN, DAN DAMPAK}

Tabel 1 mendeskripsikan hasil dari kegiatan KKN PPM tematik mangrove yang dilaksanakan selama 35 hari di 3 dusun di Desa Tirtohargo.

Tabel 1. Kegiatan KKN PPM Tematik Mangrove di Desa Tirtohargo

\begin{tabular}{|c|c|}
\hline No & Kegiatan \\
\hline 1 & Pelatihan motivasi menuju desa wisata. \\
\hline 2 & Pelatihan service excelent (pelayanan prima) untuk mempersiapkan menuju desa wisata. \\
\hline 3 & Pelatihan pembuatan kerajinan tangan dari sampah laut kayu dan limbah meubel. \\
\hline 4 & $\begin{array}{l}\text { Pelatihan pemanfaatan lahan kosong untuk ditanami buah dan toga (tanaman obat } \\
\text { keluarga) }\end{array}$ \\
\hline 5 & Pelatihan budidaya ikan air payau dan pembuatan kolam/keramba. \\
\hline 6 & Pelatihan perakitan, pemasangan, serta perawatan pembangkit listrik tenaga surya. \\
\hline 7 & Pengadaan percontohan kolam terpal di Dusun Gegunung dan Dusun Kalangan \\
\hline 8 & Pembuatan KJA/Keramba Jaring Apung di muara sungai opak. \\
\hline 9 & Pengadaan bibit ikan dan pakan ikan di 3 dusun. \\
\hline 10 & $\begin{array}{l}\text { Penanaman } 1000 \text { batang mangrove bekerjasama dengan Hizbul Wathan dan Kokam } \\
\text { Pimpinan Daerah Muhammadiyah (PDM) Bantul. }\end{array}$ \\
\hline 11 & $\begin{array}{l}\text { Pengadaan solar panel atau pembangkit listrik tenaga surya yang dipasang di pondok } \\
\text { jaga di kawasan mangrove Pantai Baros. }\end{array}$ \\
\hline 12 & $\begin{array}{l}\text { Pembangunan Green House (rumah pembibitan) di kawasan kandang terpadu } \\
\text { Kelompok Ternak Andhini Lestari Dusun Baros. }\end{array}$ \\
\hline 13 & Pengadaan bibit tanaman buah dan toga di 3 dusun. \\
\hline 14 & Pembangunan Dermaga Mini Pantai Baros dan jembatan bambu di kawasan konservasi. \\
\hline 15 & $\begin{array}{l}\text { Menganalisis data yang akan ditampilkan dalam website KP2B sebagai media promosi } \\
\text { eko eduwisata mangrove. }\end{array}$ \\
\hline 16 & $\begin{array}{l}\text { Merancang dan Mendesain website KP2B sebagai media promosi eko eduwisata } \\
\text { mangrove. }\end{array}$ \\
\hline 17 & Merancang dan membuat media promosi berupa brosur. \\
\hline 18 & Pembersihan sampah di kawasan konservasi. \\
\hline 19 & Pengadaan buku bacaan anak yang bertema lingkungan. \\
\hline
\end{tabular}

Program KKN PPM tematik mangrove di Desa Tirtohargo ini bertujuan untuk mendukung program desa dan program pemerintah daerah kabupaten Bantul yang mengarah kepada desa wisata minat khusus yaitu konservasi mangrove menuju ke arah pengembangan taman pesisir di Kabupaten Bantul. Pelatihan-pelatihan yang bertujuan untuk pengembangan SDM di Desa Tirtohargo antara lain adalah: (a) pelatihan menuju desa wisata; (b) pelatihan service excelent (pelayanan prima); (c) pelatihan pemanfaatan sampah kayu laut dan limbah meubel untuk dijadikan souvenir daerah wisata; (d) pelatihan pemanfaatan lahan kosong di sekitar lahan mangrove dan di sekitar tempat tinggal untuk dimaksimalkan untuk budidaya air payau. 


\section{a. Pelatihan Menuju Desa Wisata}

Pelatihan menuju desa wisata diarahkan untuk menguatkan SDM atau warga masyarakat sekitar untuk menuju ke arah desa wisata dengan dilatarbelakangi alasan bahwa Tirtohargo merupakan sebuah kawasan pedesaan yang memiliki beberapa karakteristik khusus sehingga dapat menjadi daerah tujuan wisata, seperti tampak pada Gambar 1. Alasan pentingnya menuju desa wisata adalah sebagai berikut: (1) ekonomi, untuk meningkatkan perekonomian masyarakat; (2) sosial, untuk membuka lapangan usaha bagi masyarakat; (3) pendidikan, untuk memperluas wawasan cara berpikir masyarakat baik masyarakat yang tinggal di sekitar desa wisata atau masyarakat yang mengunjungi kawasan desa wisata; (4) ilmu pengetahuan, untuk meningkatkan ilmu pengetahuan di bidang kepariwisataan; (5) sosial budaya, untuk menggali dan mengembangkan kesenian dan kebudayaan setempat. Hal yang dikemukakan pada saat pelatihan menuju desa wisata ini adalah beberapa hal yang mempengaruhi pengembangan sebuah desa untuk menjadi desa wisata yaitu seperti pentingnya: (1) pembangunan SDM; (2) kemitraan; (3) promosi; (4) festival; (5) kerjasama dengan pihak swasta, universitas, atau stakeholder terkait.

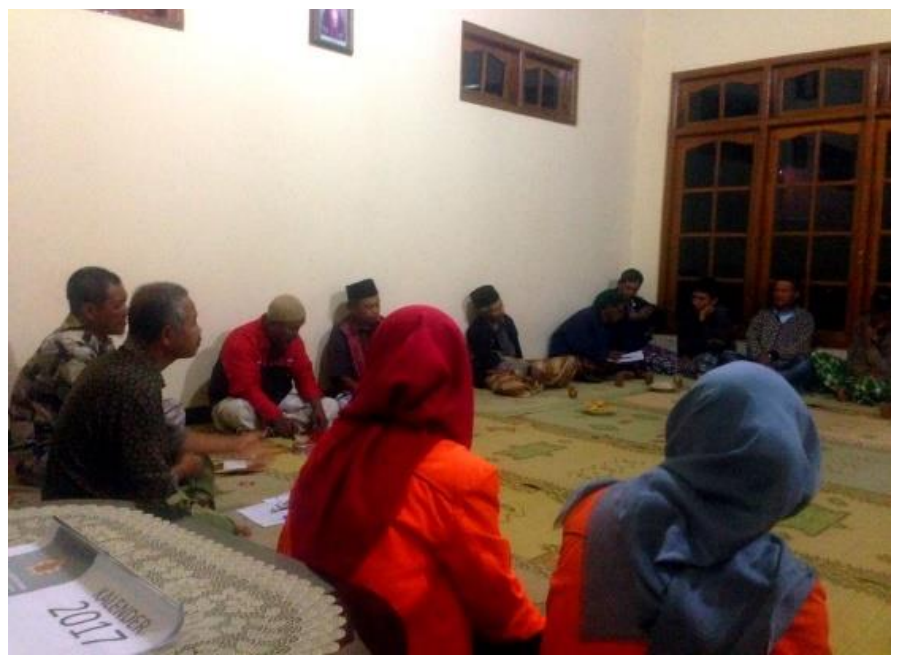

Gambar 1. Suasana Pelatihan yang Dilakukan Malam Hari Bersama Warga

\section{b. Pelatihan Pemanfaatan Sampah Laut yang Berupa Kayu dan Kayu Limbah Meubel}

Pelatihan selanjutnya adalah pelatihan pemanfaatan sampah laut yang berupa kayu serta pemanfatan limbah/sisa kayu mebel, seperti tampak pada Gambar 2. Banyaknya sampah laut berupa kayu di daerah muara sungai yang terbawa air sungai dan berhenti tersangkut menumpuk di muara sungai dapat menyebabkan pertumbuhan mangrove menjadi terhambat. Sampah kayu yang ditemukan di laut tersebut dapat dimanfaatkan untuk kerajinan, bahkan bisa bernilai jual tinggi terlebih sampah kayu laut yang terombang ambing dan terendam di sungai/muara mempunyai tekstur yang khas yang berongga di tengah sehingga menghasilkan nilai jual yang tinggi dan dapat diekspor ke mancanegara. 


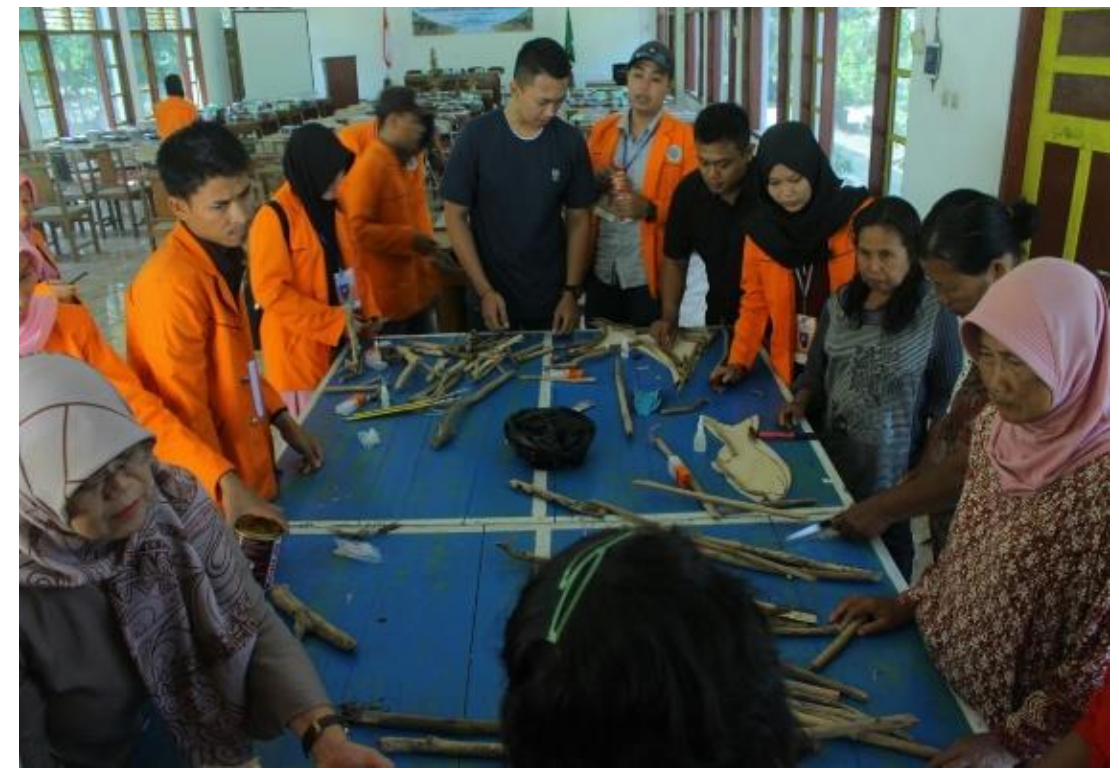

Gambar 2. Suasana Pelatihan Pemanfaatan Sampah Laut Kayu

Begitu pula adanya sisa limbah kayu meubel yang banyak dijumpai di tengah masyarakat Tirtohargo dapat pula dimanfaatkan menjadi kerajinan tangan yang bernilai tinggi, seperti tampak pada Gambar 3. Hal itulah yang melatarbelakangi diadakannya pelatihan kerajinan tangan dalam program KKN PPM UAD di Desa Tirtohargo.

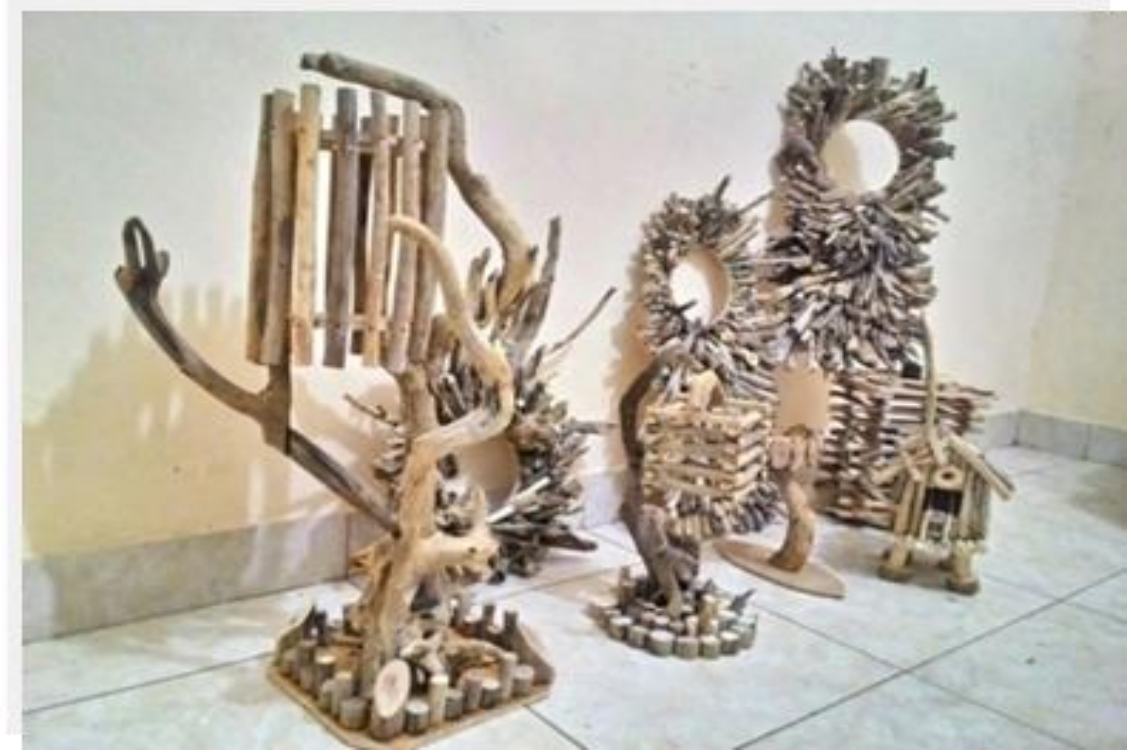

Gambar 3. Produk hasil pelatihan sampah laut kayu

\section{c. Pelatihan Budidaya Ikan Air Payau}

Materi dalam pelatihan budidaya ikan air payau tersebut meliputi teknik budidaya ikan di air payau dan karakteristik jenis ikan yang dapat dibudidayakan di air payau. Mahasiswa KKN memberikan pelatihan budidaya ikan air payau dan pembuatan kolam keramba di muara sungai opak dengan harapan agar masyarakat sekitar dapat memanfaatkan lahan di sekitar tanaman mangrove untuk budidaya ikan. Dampak setelah diadakannya pelatihan tersebut, masyarakat jadi mengetahui pemanfataan lahan di sekitar mangrove khususnya pada zona pemanfaatan terbatas untuk digunakan sebagai lahan budidaya ikan di sekitar muara sungai opak. 


\section{d. Pelatihan Pembuatan KJA dan Kolam Terpal}

Materi tentang pembuatan KJA meliputi kelebihan dan kekurangan penggunaan KJA dalam budidaya ikan, persyaratan penentuan lokasi yang akan dibangun KJA, serta desain dan kontruksi KJA, seperti tampak pada Gambar 4. KJA merupakan wadah pemeliharaan ikan terbuat dari jaring yang dibentuk segi empat atau silindris yang diapungkan dalam air permukaan menggunakan pelampung dan kerangka kayu, bambu, atau besi, serta sistem penjangkaran. Penggunaan KJA untuk wadah dalam pemeliharaan ikan apabila sirkulasi air baik maka akan mempunyai beberapa kelebihan antara lain: (1) tingkat kepadatan ikan bisa tinggi, untuk nila merah dapat mencapai 500 ekor/m3; (2) pertumbuhan ikan akan cepat sekitar 3 sampai dengan 4 bulan; (3) kualitas daging akan padat, bersih, lebih enak; (4) lebih mudah dalam budidaya dan pemanenan (tinggal angkat jaring). Adapun budidaya ikan dengan KJA juga mempunyai kekurangan yaitu: (1) jauh dari tempat tinggal sehingga ada kemungkinan mudah untuk dicuri; (2) ikan akan terlepas langsung ke perairan umum jika jaring koyak atau rakit tenggelam; (3) jika perairan tercemar atau terkena wabah akan sulit diatasi.

Materi yang lain yang disampaikan adalah mengenai persyaratan penentuan lokasi untuk KJA. Lokasi untuk KJA seharusnya diletakkan di teluk yang terlindung dari ombak dan badai serta memiliki pola penggantian massa air yang lancar dan bebas pencemaran. Selain itu pula lokasi yang bagus memiliki parameter kualitas air yang baik, seperti di antaranya: salinitas 033 ppt (dengan perubahan salinitas harian tidak lebih dari $10 \mathrm{ppt}$ ); temperatur 25-32 derajat C; $\mathrm{pH}$ berkisar 6,5-8,5; oksigen terlarut 4-8 ppm; kecepatan arus 10-20 cm/dt; pasang surut dan tinggi gelombang $<3 \mathrm{~m}$.

Adapun desain dan konstruksi KJA terdiri dari: (1) kerangka: dapat dibuat dari bahan kayu, bambu atau besi yang dilapisi bahan anti karat (cat besi), pemilihan bahan untuk kerangka, sebaiknya disesuaikan dengan ketersediaan bahan di lokasi budidaya dan nilai ekonomis dari bahan tersebut; (2) pelampung: berfungsi untuk mengapungkan kerangka/jaring terapung; bahan yang digunakan sebagai pelampung berupa drum (besi atau plastik) yang berkapasitas 200 liter, busa plastik (stereofoam) atau fiberglass; jenis pelampung yang akan digunakan biasanya dilihat berdasarkan lama pemakaian; (3) pengikat, digunakan untuk mengikat kerangka jaring terapung, pelampung atau jaring; tali pengikat sebaiknya terbuat dari bahan yang kuat, seperti tambang plastik, kawat ukuran $5 \mathrm{~mm}$, besi beton ukuran $8 \mathrm{~mm}$ atau $10 \mathrm{~mm}$; (4) jangkar, berfungsi sebagai penahan jaring terapung agar rakit jaring terapung tidak hanyut terbawa oleh arus air dan angin yang kencang; terbuat dari bahan batu, semen cor atau besi; pemberat diberi tali pemberat/tali jangkar yang terbuat dari tambang plastik yang berdiameter sekitar $10 \mathrm{~mm}-15 \mathrm{~mm}$; jumlah pemberat untuk satu unit jaring terapung empat petak/kantong adalah sebanyak 4 buah; pemberat diikatkan pada masing-masing sudut dari kerangka jaring terapung, berat jangkar berkisar antara $50-75 \mathrm{~kg}$; (5) Jaring, terbuat dari bahan polyethylene; ukuran mata jaring yang digunakan tergantung dari besarnya ikan yang akan dibudidayakan; ukuran yang biasa digunakan jaring polyethylene no. 280 D/12 dengan ukuran mata jaring 1 inch $(2,5 \mathrm{~cm})$ atau 1,5 inch $(3,81 \mathrm{~cm})$; jaring yang mempunyai ukuran mata jaring lebih kecil dari 1 inch biasanya digunakan untuk memelihara ikan yang berukuran lebih kecil; (6) jaring, berfungsi sebagai penahan agar jaring tetap simetris; diletakkan pada setiap sudut kantong jaring terapung; pemberat yang digunakan biasanya terbuat dari semen cor yang masing-masing beratnya antara $2-5 \mathrm{~kg}$. 


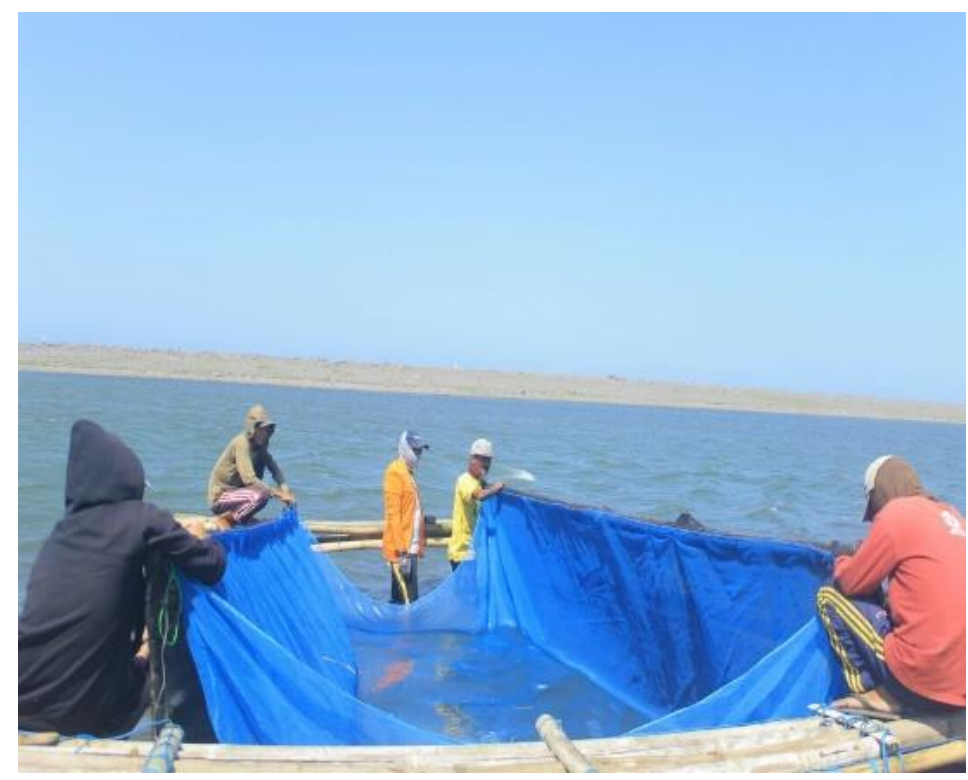

Gambar 4. Pembuatan keramba jaring apung (KJA) di Muara Sungai

Harapan diadakannya pelatihan ini nantinya KJA (Keramba Jaring Apung) yang dibangun dapat menjadi pilot project masyarakat setempat. Sedangkan di dua dusun lain sebagai dusun penyangga kawasan konservasi yang tidak mempunyai muara, maka dibuatkan pilot project kolam sistem terpal dengan menggunakan batako.

Adapun materi yang diberikan pada saat pelatihan pembuatan kolam terpal meliputi halhal dalam pembuatan kolam terpal dan langkah-langkah pembuatan kolam terpal, seperti tampak pada Gambar 5. Hal- hal yang perlu diperhatikan dalam pembuatan kolam terpal yaitu lokasi (persawahan atau pekarangan), sistem pengairan (dekat sungai atau tidak), fungsi dan rencana pemeliharaan (untuk kolam pendederan atau pembesaran). Prinsip-prinsip pembuatan kolam terpal antara lain: (1) alas/dasar tanah bebas dari bahan tajam yang kemungkinan dapat membuat terpal mudah bocor atau robek; (2) dasar tanah diberi skam padi setebal $10-15 \mathrm{~cm}$; (3) pematang kolam dapat terbuat dari bahan (belahan bambu, tanah/pasir, batako ) atau lainnya asalkan dapat menahan beban volume air kolam; (4) tidak perlu dilakukan pengeringan dasar kolam; (5) terpal bagian atas pematang ditutup dengan batu bata/batako maupun bahan lain yang dapat melindungi dari sinar matahari.

Tahapan dalam pembuatan kolam terpal adalah sebagai berikut. (1) Persiapan. Begitu pemasangan terpal selesai, saat itu pula segera diairi, dan proses pengairan sebaiknya sedikit demi sedikit, karena dengan begitu terpal akan mapan dengan baik ; agar terpal tidak mudah rusak, semua bagian harus tertutup baik dengan batako ataupun dengan air, oleh karena itu air harus penuh, apabila hujan tumpahan air akan mengalir disela-sela batako; setelah pengisian air penuh diberikan pupuk cair (probiotik) dengan cara dipercikkan secara merata; air kolam jangan sampai tumpah karena pupuk cair akan terbuang; setelah penuh, 3 hari sebelum penebaran benih, sebarkanlah garam dapur (krosok) 200 gram/m3 air secara merata di kolam sebagai desinfektan; kolam didiamkan selama 7 hari untuk penumbuhan pakan alami; penebaran benih lele pada hari ke-8, ukuran 7 - $9 \mathrm{~cm}$ dengan kepadatan 100 ekor/m2; penebaran benih dilakukan pagi hari sebelum jam 8 , atau sore hari menjelang senja. 


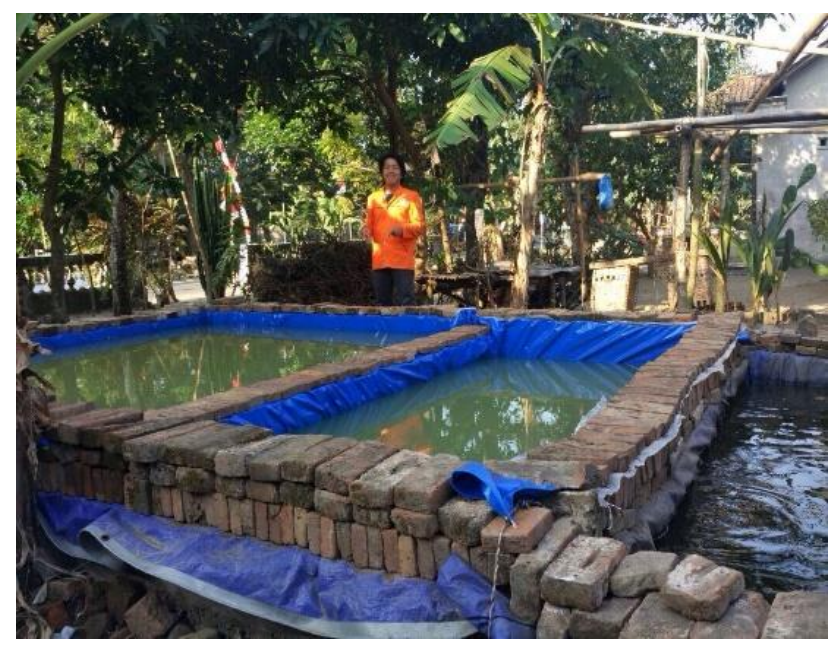

Gambar 5. Kolam terpal di 2 Dusun penyangga

\section{e. Pelaksanaan Kegiatan Peduli Lingkungan}

Kegiatan peduli lingkungan yang dilaksanakan adalah kegiatan penanaman 1000 batang tanaman mangrove bersama-sama dengan masyarakat sekitar dan juga bekerja sama dengan Lembaga Penanggulangan Bencana, Kokam, seperti tampak pada Gambar 6.

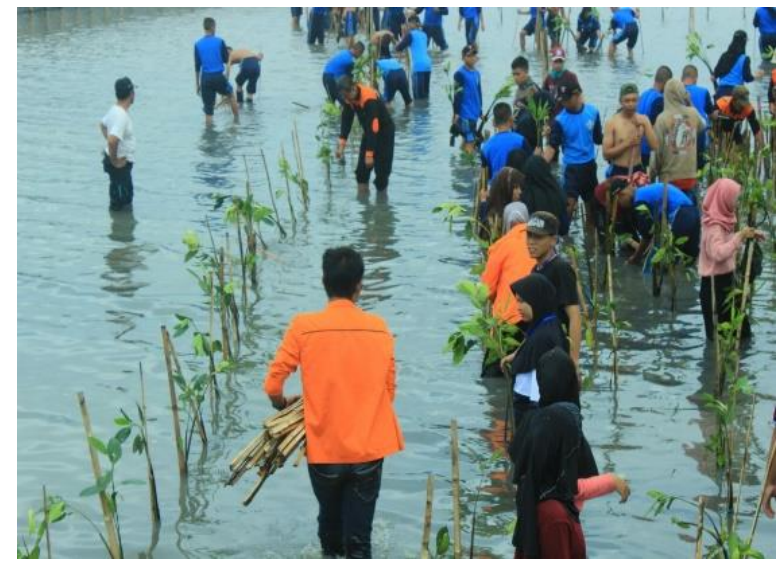

Gambar 6. Penanaman mangrove bersama dengan siswa SMK dan warga masyarakat sekitar

Selain itu, sejumlah tokoh juga ikut melakukan penanaman mangrove bersama, diantaranya Hizbul Wathan Pimpinan Daerah Muhammadiyah Kabupaten Bantul, seperti tampak pada Gambar 7.

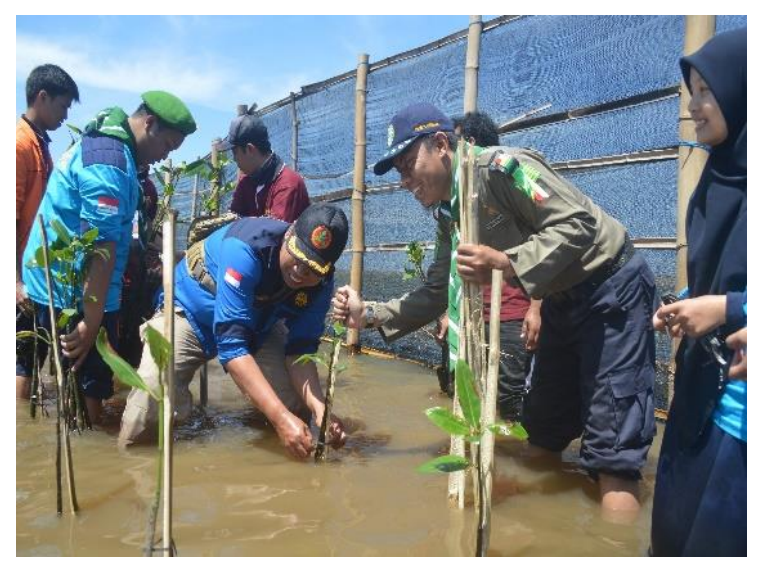

Gambar 7. Penanaman mangrove bersama dengan Lembaga Penanggulangan Bencana dan Hizbul Wathan Pimpinan Daerah Muhammadiyah Bantul 
Setiap hari minggu mahasiwa bersama-sama dengan KP2B melakukan bersih pantai. Hasil sampah yang berupa kayu laut dibuat menjadi souvenir atau kerajinan tangan, dan sampah laut yang berupa sandal dirangkai sebagai dinding pembatas. Harapannya hal tersebut bisa menjadi pioner atau mengawali setiap kegiatan peduli lingkungan yang dilakukan para wisatawan di tempat tersebut. Para wisatawan diharapkan selain datang untuk menanam mangrove, setiap kembali dari menyusuri pantai ikut membawa sampah laut yang ditemuinya di sepanjang pantai sebagai wujud nyata peduli lingkungan yaitu menyelamatkan pantai dari sampah, seperti tampak pada Gambar 8.

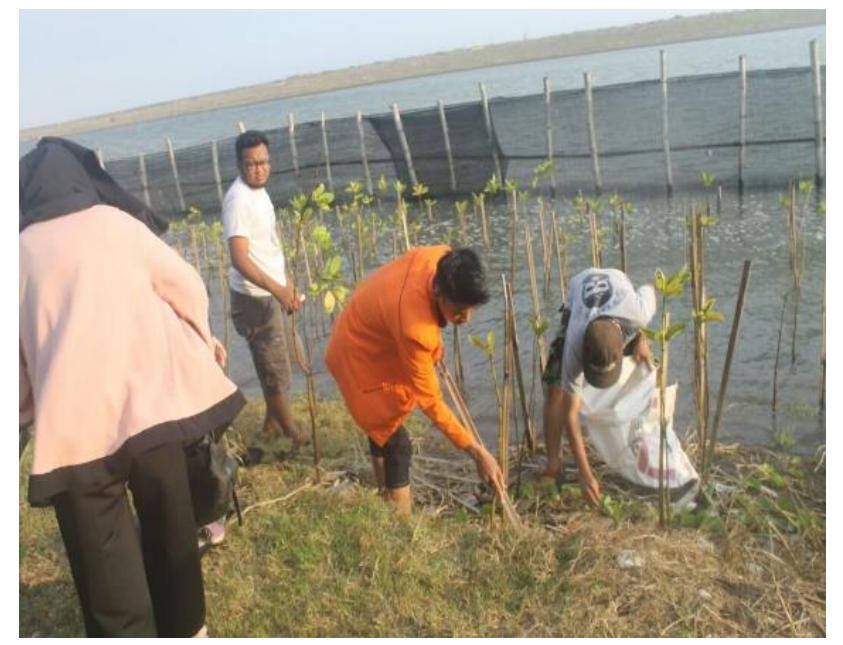

Gambar 8. Pembersihan sampah di Sekitar Lokasi Penanaman Mangrove

\section{f. Pembangunan Green House (Rumah Pembibitan) di Area Kandang Terpadu}

Pengadaan dan pembangunan rumah pembibitan di area kandang terpadu oleh mahasiswa KKN UAD bersama dengan Kelompok Ternak Kandang Andhini mempunyai harapan bahwa kawasan kandang terpadu dapat dimanfaatkan semaksimal mungkin untuk pembibitan bermacam tanaman buah atau tanaman obat keluarga sehingga dapat memanfaatkan kotoran ternak yang ada di sekitar kandang untuk dijadikan pupuk sekaligus dapat dijadikan arena edukasi tatacara pembibitan dan penanaman kepada para wisatawan yang datang ke area konservasi mangrove mengingat ke depan konsep pengembangan kawasan baros bertema Pengembangan Kawasan Konservasi Mangrove Berbasis Eko Eduwisata Mangrove, seperti tampak pada Gambar 9.

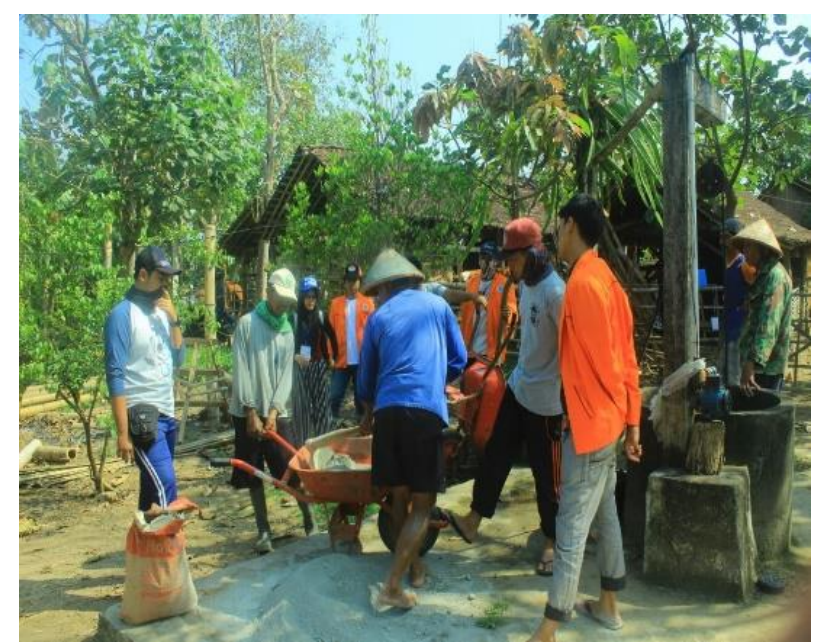

Gambar 9. Mahasiswa Bersama Masyarakat Membangun Green House 


\section{g. $\quad$ FGD Bersama dengan Bappeda Bantul dan SKPD Terkait}

FGD yang dilakukan mahasiswa KKN tersebut bertujuan untuk mempertemukan stake holder terkait, atau pemangku kebijakan atas pengembangan kawasan konservasi mangrove di Baros Tirtohargo ini dengan mengundang Bappeda Bantul, Dinas Lingkungan Hidup Kabupaten Bantul, Kecamatan Kretek, Pemerintah Kelurahan Tirtohargo, Dinas Pertanian dan Peternakan Kabupaten Bantul, Dinas Pariwisata Kabupaten Bantul serta SKPD terkait serta tak lupa KP2B sendiri sebagai pelaksana konservasi, seperti tampak pada Gambar 10.

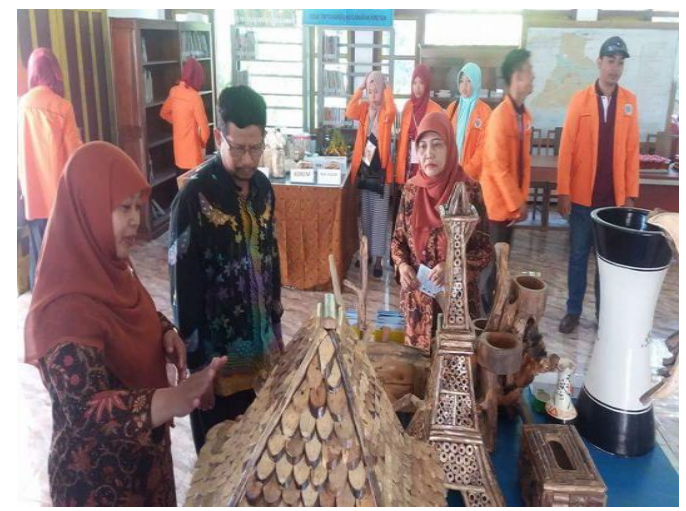

Gambar 10. Hasil pelatihan dan potensi yang ada di 3 Dusun dipamerkan saat FGD

Saat FGD berlangsung turut dipamerkan hasil pelatihan berupa pemanfaatan sampah laut yang berupa kayu ataupun pemanfaatan limbah meubel kayu. Selain itu juga, FGD juga melibatkan masyarakat dengan turut serta menampilkan potensi yang ada di masing-masing dusun, seperti potensi adanya tanaman jahe, potensi budidaya jamur, potensi tanaman bawang merah dan bawang putih, serta adanya potensi pembuatan gerabah, seperti tampak pada Gambar 11.

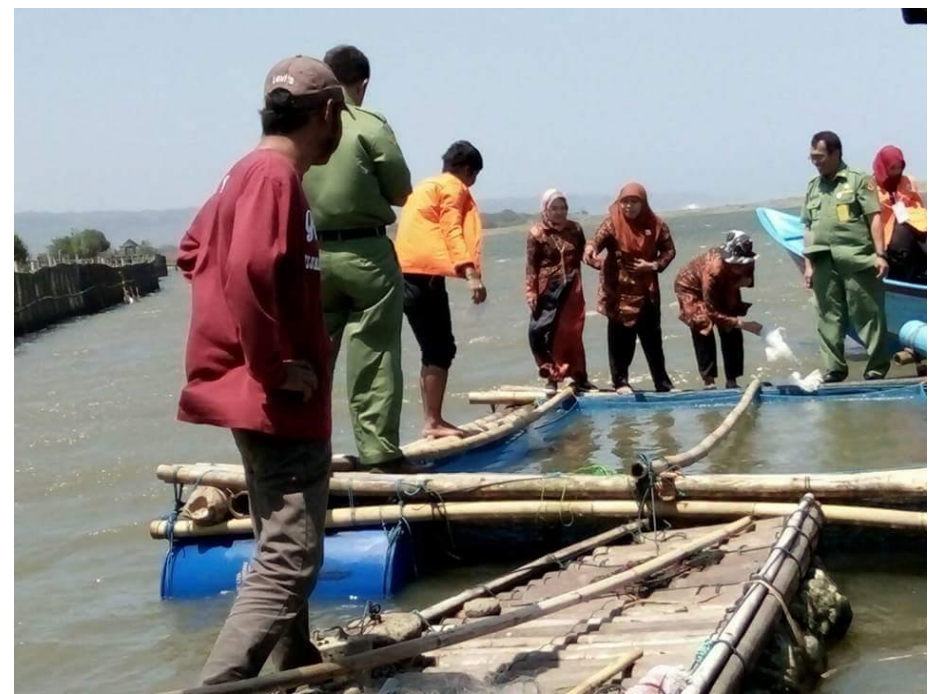

Gambar 11. FGD diakhiri dengan pelepasan bibit Ikan di KJA setelah sebelumnya berkeliling di Area Konservasi Mangrove

\section{h. Pengadaan Solar Panel atau Pembangkit Listrik Tenaga Surya}

Pengadaan solar panel atau pembangkit listrik tenaga surya dilatarbelakangi permasalahan kurangnya pasokan listrik di pondok jaga KP2B sehingga menyebabkan pompa air tidak dapat berfungsi secara optimal untuk menaikkan air dari sumur sampai ke tandon penampungan air di atas atap lantai dua bangunan di pondok jaga tersebut. Selama ini listrik di pondok jaga tersebut mendapat pasokan listrik dari desa yang berjarak sekitar 500 meter dari 
pondok jaga. Jarak tersebut menyebabkan listrik yang melalui penghantar kabel kurang dapat maksimal ketika digunakan untuk menaikkan air menggunakan pompa air di pondok jaga. Hal inilah yang menjadi alasan pertama perlunya pengadaan solar panel selain juga mengingat perlunya energi listrik alternatif dari sumber daya alam yaitu panas terik matahari dapat dimanfaatkan untuk pembangkit listrik. Sebelum dilakukan pengadaan solar panel di pondok jaga, terlebih dahulu diadakan pelatihan perakitan dan penghitungan kebutuhan untuk pembuatan solar panel, seperti tampak pada gambar 12 .

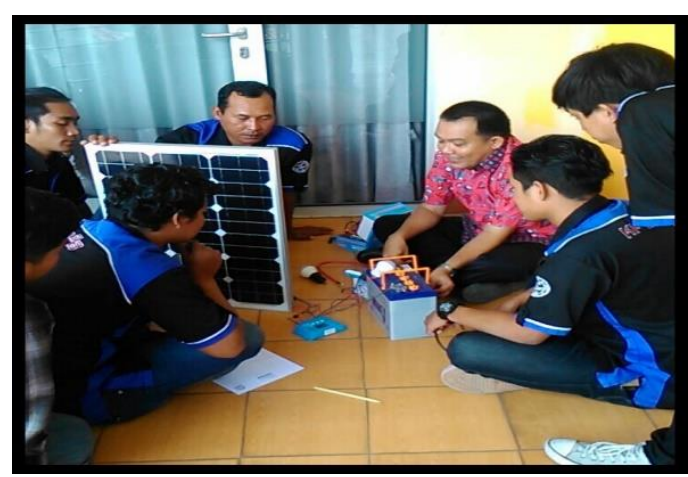

Gambar 12. Pelatihan perakitan solar panel berkolaborasi dengan dosen Teknik Informatika

\section{i. Pembangunan Dermaga Mini Pantai Baros dan Jembatan Bambu}

Pembangunan dermaga mini dilakukan dengan bergotong royong antara KP2B (Keluarga Pemuda Pemudi Baros) dengan KKN PPM UAD 2017. Bahan yang digunakan dari bambu. Semula sebelum ada KKN UAD, muara sungai opak di kawasan konservasi mangrove belum mempunyai dermaga tempat berlabuhnya kapal-kapal nelayan atau kapal-kapal wisata, tetapi mulai sekarang sudah mempunyai dermaga mini untuk berlabuhnya kapal nelayan. Selain sebagai tempat berlabuh, dermaga ini dapat digunakan oleh wisatawan sebagai tempat fotofoto, seperti tampak pada Gambar 13.

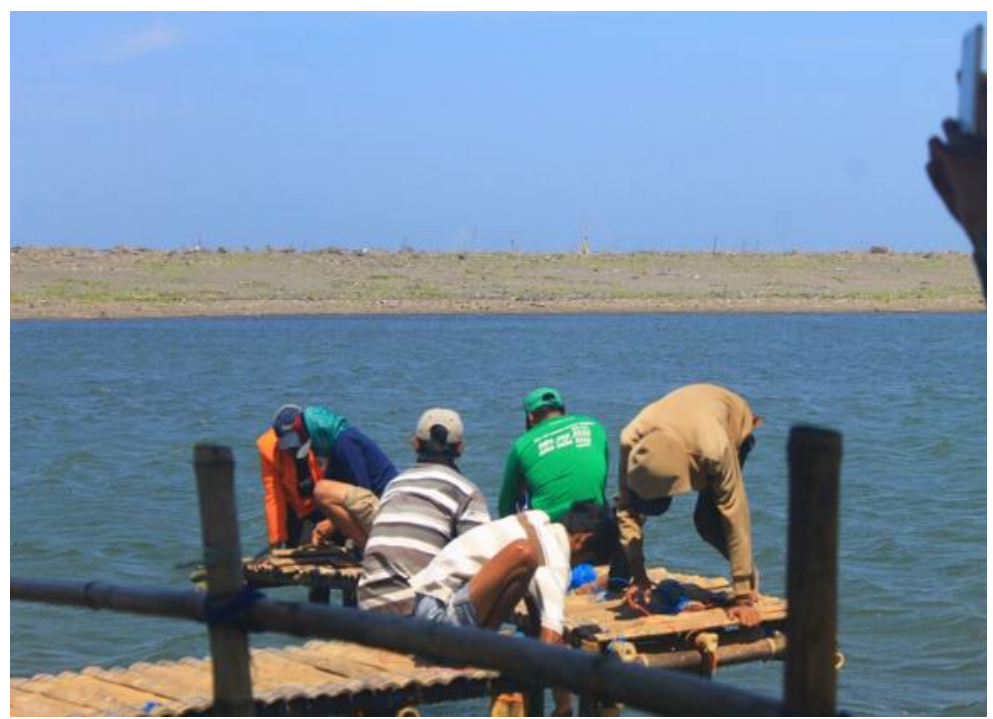

Gambar 13. Pembuatan dermaga mini di Muara Sungai Opak

\section{SIMPULAN}

Potensi yang ada di kawasan konservasi mangrove ini diharapkan menjadi habitat unik untuk mangrove dan binatang lain yang berada di sekitar tanaman mangrove, sehingga perlu perhatian semua elemen masyarakat untuk mendukung terciptanya kawasan konservasi 
mangrove dengan mengetahui dan mematuhi Peraturan Bupati tentang pencadangan kawasan taman pesisir yang akan digunakan sebagai konservasi mangrove. Kelompok sadar wisata (dalam hal ini KP2B sebagai kelompok konservasi mangrove) yang sudah dibina dapat meningkatkan kelembagaan dengan mitra yang lainnya, baik pihak swasta ataupun pihak pemerintah dalam hal mengembangkan dan memperkenalkan potensi wisata edukatif dan wisata alam kepada masyarakat.

Program-program yang diinisiasi oleh KKN PPM UAD ini diharapkan dapat dilanjutkan oleh berbagai pihak (pemerintah setempat ataupun stakeholder lain) agar dapat meningkatkan kesejahteraan masyarakat pesisir sekitar lokasi konservasi dengan menjadikan wilayah konservasi sebagai aset wisata minat khusus yang bernilai edukatif bagi semua lapisan masyarakat. Tentunya perlu ditunjang dengan beberapa sarana untuk kegiatan outbound, camping ground, atau homestay dan adanya warung-warung kuliner untuk menjadikan kawasan ini salah satu tujuan wisata minat khusus tersebut. Terlebih mengingat bahwa kawasan ini sudah memiliki bangunan selamat datang di pintu masuk kawasan sebagai Icon Branding kawasan mangrove Pantai Baros. Harapan ke depan, potensi yang sekarang dikembangkan oleh KKN PPM UAD dapat ditindaklanjuti secara menyeluruh dari semua pihak yang berwenang.

\section{UCAPAN TERIMA KASIH}

Pada kesempatan ini, tim penulis menyampaikan terima kasih kepada semua pihak yang telah memberikan bantuan, arahan, sehingga Program KKN PPM tematik mangrove di wilayah Baros dapat terlaksana dengan baik. Ucapan terima kasih kami sampaikan kepada beberapa pihak berikut ini.

1. Bappeda Bantul yang telah memberikan izin dan pengarahan terkait kebijakan Pemerintah Daerah Kabupaten Bantul sehubungan dengan program tematik mangrove ini.

2. Kecamatan Kretek dan Kelurahan Tirtohargo yang telah memberikan bantuan fasilitas tempat dan sarana serta prasarana selama melaksanakan KKN PPM.

3. Dinas terkait dalam hal ini BLH Bantul, Dinas Perikanan dan Peternakan Kabupaten Bantul, dan Dinas Pariwisata Kabupaten Bantul yang telah memberikan arahan terhadap program KKN PPM tematik Mangrove di Desa Tirtohargo ini.

4. Kelompok konservasi mangrove KP2B yang telah memberikan ruang kepada para mahasiswa KKN UAD untuk bersinergi dalam semua kegiatan konservasi mangrove.

5. CV Pitoyo Indo Furniture yang telah memberikan bantuan melatih pemanfaatan sampah kayu laut, mengikutkan produk hasil KP2B dalam pameran-pameran baik lokal, nasional, ataupun internasional.

6. Lembaga Penanggulangan Bencana Pimpinan Daerah Muhammadiyah Bantul yang telah bersinergi bersama dengan Kokam dan Hizbul Wathannya untuk mendampingi mahasiswa UAD dalam kegiatan penanaman mangrove.

\section{DAFTAR PUSTAKA}

Kordi, G.H. (2012). Ekosistem Mangrove: Potensi, Fungsi, dan Pengelolaan. Jakarta: Rineka Cipta. 
